\title{
Ghosts of the past: The competing agendas of forensic work in identifying the missing across Bosnia and Herzegovina
}

Admir Jugo Goldsmiths, University of London ajugo010@gold.ac.uk

Senem Škulj University of Sarajevo

senem_skulj@hotmail.com

\begin{abstract}
International interventions in Bosnia and Herzegovina, that ultimately brought the war to a standstill, emphasised recovering and identifying the missing as chief among the goals of post-war repair and reconstruction, aiming to unite a heavily divided country. Still, local actors keep showing that unity is far from achieved and it is not a goal for all those involved. This paper examines the various actors that have taken up the task of locating and identifying the missing in order to examine their incentives as well as any competing agendas for participating in the process. These efforts cannot be understood without examining their impact both at the time and now, and we look at the biopolitics of the process and utilisation of the dead within. Due to the vastness and complexity of this process, instead of a conclusion, additional questions will be opened required for the process to keep moving forward.
\end{abstract}

Key words: Bosnia and Herzegovina, ICMP, Yugoslavia, forensic, biopolitics

\section{Introduction}

The end of the war in Bosnia and Herzegovina $(\mathrm{BiH})$, at least the one fought with weapons, was marked by the signing of the General Framework Agreement for Peace, more commonly known as the Dayton Peace Agreement (DPA), by the warring parties. After the signing, around 100,000 casualties were recorded and around 31,500 persons were registered as missing. ${ }^{1}$ These disappearances were mostly a result of mass executions with the victims' burial in mass graves across the country and its neighbours. Katherine Verdery writes that 'dead bodies have enjoyed political life the world over and since far back in time ${ }^{\prime 2}$, and it is therefore no surprise that such was the case with the dead bodies resulting from the war in $\mathrm{BiH}$. Today, BiH's landscape is marked with once clandestine but now mostly exhumed mass graves. These graves are a harrowing reminder of those that have gone and their suffering, and of the unsettled ghosts of the past that still haunt the present. These ghosts are kept in limbo through the never-ending 'transition' of $\mathrm{BiH}$ and the ongoing search for the missing in an effort to enable their surviving 
family members to restore their identities to material human remains, to be remembered and commemorated.

International interventions in $\mathrm{BiH}$, which ultimately brought the war to a standstill, began as early as 1992, from the conflict's very start. The United States' international CIA played an important role in the public discovery of mass graves. ${ }^{3}$ This attention however led to the subsequent retrieval and reburial of large numbers of human remains in various secondary locations, in an attempt by one of the warring parties to hide the evidence of their crimes. This intentional disturbance has posed a great challenge to the recovery and identification of the missing, processes that 'were chief among the goals of repair and reconstruction' for the international community in post-war $\mathrm{BiH}$ and leading towards the hope of uniting a heavily divided country. ${ }^{4}$ With the formation of the ad hoc tribunal for the former Yugoslavia in 1993, these processes were dealt within the scope of international law, namely International Humanitarian Law and International Criminal Law.

International Humanitarian Law sets out provisions for accounting for persons missing from conflicts, especially in the Geneva Conventions and their Additional Protocols establishing 'the right of families to know the fate of their [disappeared] relatives ${ }^{\prime 5}$ regardless of the nature of the armed conflict, whether international or civil. In 1974 the United Nations General Assembly passed a resolution stating that 'the desire to know the fate of loved ones lost in armed conflicts is a basic human need which should be satisfied to the greatest extent possible', highlighting that the provision of information to families of the missing should not be delayed because other issues are pending and being resolved. ${ }^{6}$ Furthermore, the International Convention for the Protection of All Persons from Enforced Disappearance states that 'each victim has the right to know the truth regarding the circumstances of the forced disappearance, the progress and results of the investigation and the fate of the disappeared person. Each State Party shall take appropriate measures in this regard. ${ }^{7} \mathrm{BiH}$, which ratified these documents, has an obligation to resolve the fate of those that have gone missing as a result of the war.

This paper attempts to examine the various actors that have taken up the task of locating and identifying the missing in order to explore their incentives as well as any competing agendas for participating in the process. This paper first gives a chronological overview of major actors in the process's plethora of participants and the changes in the process itself, and discusses their agendas and how they worked and work in relation to one another. Since these efforts cannot be understood without examining their impact both at the time and now, this paper also provides a look at the biopolitics of the process and utilisation of the dead as capital in biopolitics. Given that our analysis is unable to encompass the vastness of this multifaceted process, we have decided, instead of a conclusion, to raise additional questions that need to be addressed for the process to keep moving forward.

\section{A short history of the process}

In any war there are casualties. Throughout the war in $\mathrm{BiH}$, reports of serious breaches of the Geneva Conventions were documented. Incidences of killings 
en masse and burials in clandestine mass graves were common. Families of those killed demanded justice for crimes committed against them and thus exercised pressure on the Government to account for these crimes. Trials were conducted by local military courts as early as 1992, and both Karadžić and Mladić were indicted by the District Military Court in December that year. ${ }^{8}$ In the politics of war in $\mathrm{BiH}$, bodies of the imprisoned, killed and missing became powerful biocapital to be traded, recovered and consecrated through 'proper burials', and to be used and manipulated by different holders of biopowers at play.

Even during wartime the State and all other warring parties were taking actions to account for the missing persons. ${ }^{9}$ On 16 July 1992, the Government of $\mathrm{BiH}$ adopted a Decision on formation of the State Commission for the Exchange of Prisoners of War with a mandate to exchange prisoners of war and the remains of the fallen. ${ }^{10}$ In addition, the Commission was also tasked with documenting the fallen, injured and missing persons in the territory of $\mathrm{BiH} .{ }^{11}$ In 1996 the Government of $\mathrm{BiH}$ passed a Decision through which the Commission for the Exchange of Prisoners of War was disbanded, and the State Commission for Tracing Missing Persons was formed. ${ }^{12}$ Despite the Commission's intention to search for missing persons irrespective of any ethno-religious affiliations, the resulting investigations diverged in three different directions along ethno-religious lines. Furthermore, despite being envisioned as a State body, the Commission was financed and overseen by the entity of the Federation of $\mathrm{BiH}$, which is clear evidence of the ethno-religious divisions within the Commission. ${ }^{13}$

In addition to the State Commission, the Croatian Defence Council's (HVO) Commission on Missing Persons and the Republika Srpska's (RS) Missing Persons Commission were also active during the war. Unlike the State Commission, these two Commissions had clear ethno-religious affiliations. The HVO Commission was in charge of tracing and exchanging prisoners of war and bodies of those killed within the territory of the Croat (Roman-Catholic) governed and self-proclaimed Herceg-Bosna, namely those presumed to be Croats, while the RS Commission was interested in resolving the fate of those individuals perceived to be of a Serb (Orthodox-Christian) ethno-religious affiliation.

The war ended through the signing of the DPA in December 1995, and the issue of missing persons was included into the Dayton Agreement itself, with Article $\mathrm{V}$ of Annex 7 stating that 'the Parties shall provide information through the tracing mechanisms of the ICRC [International Committee of the Red Cross] on all persons unaccounted for. The Parties shall also cooperate fully with the ICRC in its efforts to determine the identities, whereabouts and fate of the unaccounted for.' ${ }^{14}$ This provided a legal, monetary and material basis for addressing the issue of missing persons in post-war BiH. The DPA divided the country into two entities: the Federation of $\mathrm{BiH}$ and the Serb Republic, which now started dealing with the missing in their territories individually despite the existence of an official State Commission. In July 1997 the Federal Commission on Missing Persons was formed functioning through two components: Bosniak and Croat contingents. ${ }^{15}$ Each contingent searched for persons belonging to the ethno-religious group they represented: either Bosniak (Muslim) or Croat (Roman-Catholic). Members 
of the third ethno-religious group, Serbs (Orthodox Christians), were sought by the Office of Tracing Detained Prisoners and Missing Persons of the RS. All the Commissions were tasked with tracing and locating human remains, gathering information and keeping records on missing persons. ${ }^{16}$

After the DPA was signed, efforts to locate and identify missing persons intensified, but with the war just over and its memories still fresh, the Commissions had to find ways to manage the work within each other's territories. In an effort to give some structure and transparency to the process, and in an attempt to make it accessible to all formerly warring parties, the local governments and the international community agreed on the Joint Exhumation Process (JEP), administered by the Office of the High Representative (OHR), the organisation tasked with civilian implementation of the DPA. This process was based on two Agreements between the entities, the so-called Banja Luka Agreement signed on 25 June 1996 and the subsequently developed Operational Agreement on Exhumations signed on 4 September 1996. According to these agreements, the three former warring parties were free to carry out exhumations in each other's territory. ${ }^{17}$ This meant that, for example, if the RS's Commission wanted to excavate in the Federation of $\mathrm{BiH}$ 's territory (the territory under the jurisdiction of the two contingent Federal Commissions), the RS's commission would have to obtain the permission to do so from the OHR and the JEP Monitor would attend the excavation to negotiate between the different actors.

With the JEP in place, local governments started undertaking exhumations and the identification of mortal remains, with scarce international assistance provided to $\mathrm{BiH}$. A report by the then UN Special Rapporteur of the Commission on Human Rights, following her visit to a mass grave, included a public appeal for assistance in the investigations of crimes committed in the Western Balkans. ${ }^{18}$ This appeal led to the Finnish Government politically and financially supporting a mission of twenty-two Finnish experts to BiH. ${ }^{19}$ In March 1996 they started excavation work in the RS but were soon ordered by the RS authorities to refrain from any further activities. ${ }^{20}$ The cases recovered were transported to the Tuzla Clinical Centre and the Finish experts continued to provide expert assistance in anthropological analysis, something not previously done in $\mathrm{BiH}$. The Finnish support was completely humanitarian in focus and was based on a desire to give the victims an honourable handling and burial of the remains, with emphasis placed on their identification. ${ }^{21}$

The Finnish Government's approach was much different from the approach taken by the International Tribunal for the Former Yugoslavia (ICTY) which also worked on resolving the fate of the missing. The ICTY, an ad hoc tribunal set up by the UN, was given jurisdiction over the former Yugoslavia's territory, which included $\mathrm{BiH}$. Under its Statute, the ICTY has the authority to undertake investigations and exhumations in $\mathrm{BiH} .{ }^{22}$ The ICTY also holds primacy over national courts and can take over any national investigations and proceedings at any stage (both in $\mathrm{BiH}$ and the wider region). ${ }^{23}$ The first series of exhumations undertaken by the ICTY started on 7 July 1996 and, according to the ICTY, the purpose of these mass grave excavations was threefold: to corroborate witness testimony; to recover evidence related to the indictments; and to document injuries and identify the cause 
and time of death. ${ }^{24}$ The ICTY only excavated mass graves for prosecution purposes, i.e. only graves related to previously issued indictments or those indictments that were going to be issued. The identification process itself, as well as the issuing of death certificates, was left to the local Government. Between 1996 and 2001, the excavations and examinations of human remains recovered were undertaken by the ICTY. In 2001, the ICTY Chief Prosecutor determined that 'exhumations by the International Tribunal will end in 2001 as there are no more known sites of particular relevance to remaining investigations'. ${ }^{25}$ Originally, in 1996, the ICTY contracted Physicians for Human Rights (PHR) to work on exhumations in $\mathrm{BiH}$. Shortly after, however, this relationship ended and the ICTY started employing international staff for their own teams. The fact that the ICTY has been given both territorial jurisdiction and primacy, while employing international staff, clearly shows that it was set up to serve the agenda of the international community. This agenda did not necessarily differ from the agendas of other actors in the process, but it was certainly separate.

After the ICTY-PHR relationship ended, PHR started their own forensic project funded by the International Commission on Missing Persons (ICMP) in $\mathrm{BiH}$, with three parallel but separate components: the Forensic Assistance Project, the Identification Project and the Antemortem Database Project, with a particular focus on the fall of Srebrenica. ${ }^{26}$ The project's goal was to complete individual identifications. It was also through PHR's project that the first identifications using mitochondrial DNA were made. ${ }^{27}$ PHR's goal was to assist local efforts in dealing with the missing through the collection of antemortem information on the missing, collecting individualising information from human remains, comparing this data in an attempt to generate possible matches and monitoring exhumations of sites the ICTY did not deem of prosecutorial interest. PHR worked in support of local actors, with an approach that clearly differed from that employed by the ICTY.

The ICMP was established in 1996 to help deal with the issue of missing persons in the territory of the Former Yugoslavia. ${ }^{28}$ The ICMP's role expanded in 2001 when they started providing technical assistance on excavations and the examination of human remains using their own teams. ${ }^{29}$ Up until 2001, the ICMP had sub-contracted this work first to PHR and then to Kenyon International. The ICMP took a 'holistic' approach anticipating its help with the development of legal institutions, in engaging in civil society initiatives (such as appropriate commemorations) and coordinating technical assistance with the purpose of ensuring adherence to international standards. ${ }^{30}$ The approach here can be viewed as merging the 'scientific' and the 'social'. This is yet another attempt by the international community, through the ICMP, to address the issues of missing persons by unifying the emerging society's ethno-religious groups towards the same goal of reconciliation.

The ICMP worked with established protocols and standards but revolutionised the approach through employing high-throughput DNA technology for the purposes of identifying the missing in the Former Yugoslavia's territory. ${ }^{31}$ This approach also relied on the family members of the missing persons to provide their DNA samples for comparison with DNA isolated from recovered human remains. On 16 November 2001 the ICMP obtained the first DNA match that 
led to an identification of a set of human remains. ${ }^{32}$ The ICMP also played and continues to play a role in $\mathrm{BiH}$ 's legal and social issues. It works with associations of families of missing persons actively empowering them to be included in the process of searching for the missing in cooperation with State institutions. ${ }^{33}$ The contributions of the ICMP towards the legal framework of the process in $\mathrm{BiH}$ has resulted in the adoption of the Law on Missing Persons by the $\mathrm{BiH}$ Parliamentary Assembly in $2004^{34}$ and the creation of a state-level institution specifically tasked with implementing the Law and resolving the fate of the missing: the Missing Persons Institute (MPI). ${ }^{35}$

MPI was co-founded by the $\mathrm{BiH}$ Council of Ministers and the ICMP in 2005 but became fully operational in 2008 when the state and entity Commissions on missing persons were disbanded. ${ }^{36}$ Like the State Commission before it, the MPI was envisioned to encompass all ethno-religious groups and to search for any and all citizens of $\mathrm{BiH}$ indiscriminately. The families of the missing were now involved in the MPI as members of its Advisory Board. The Law on the missing gave families power over the identification process insofar as identifications of the missing are only valid if the family members agree to and accept them. ${ }^{37}$

Through the active involvement of the MPI, it seemed that the unity pushed for by international actors was overcoming the ethno-religious divisions that had marked post-war $\mathrm{BiH}$ and were inscribed in the DPA in the form of entities. This hope was however short-lived as the RS Government decided to form its own RS Operational Team in June 2008, just five months after the MPI became operational, claiming that the state-level institutions did not work for all ethnicities. ${ }^{38}$ This team was tasked with tracing and identifying missing persons in the territory of RS, clearly competing with the work of the MPI. The establishment of the RS Operational Team was also marked by a large departure of the MPI's Serb employees who joined the Operational Team, thus giving the appearance of legitimacy to the RS Government's endeavour.

The story of the process of tracing and identifying the missing in $\mathrm{BiH}$, and in the wider territory of the former Yugoslavia, is one of success with over seventy per cent of the roughly 40,000 reported missing being accounted for, but it is not without its challenges, problems and repercussions. ${ }^{39}$ As the actors in this process changed, their agendas competed for the definition of the end-goal and the process went through several technical changes. The 'traditional' individual identifications used in the early days (visual identification, identification through artefacts, witness information etc.) proved to be unsuccessful, unsatisfactory and erroneous. ${ }^{40}$ They were employed because the technology used in identifications in $\mathrm{BiH}$ today, namely DNA analysis, was not as well developed and required higher investments, which the state could not afford, and the ICTY was not interested in these individual identifications. This was also the time when storage of remains was quite chaotic and unsuitable for these purposes. Since the possibility of employing DNA technology was unavailable at the time, the state faced a rising problem of the storage of dead bodies. With the ICTY starting up operations in $\mathrm{BiH}$ and the pressures of family members for dignified burials, the state was forced to start attempting to identify the dead. 
At the time, identifications were under the authority of the local government and were conducted through visual inspection of the remains by family members, dental comparison, utilising ante-mortem data, medical records and presumptive identification through artefacts, witness information and other so-called 'traditional' techniques. Full anthropological examination was conducted by a pathologist in order to obtain an individual biological profile of victims. These profiles proved to be very limited in their power to be useful for identification, especially given that foreign anthropological standards were originally utilised for lack of any previous $\mathrm{BiH}$ specific standards. In order to overcome these obstacles, local and international researchers started subjecting bodies to scientific examination in order to produce scientific standards that would more accurately individualise the bodies. It was soon realised that some of these studies might be erroneous as they were based on bodies with unreliable ante-mortem data, where identifications were made without DNA and where bodies might have been misidentified. ${ }^{41}$ Nevertheless this proliferation of studies on anthropological characteristics of the dead in $\mathrm{BiH}$ also meant an increase in its knowledge production of the dead. This knowledge was now a commodity that was being exported in the form of Master's and $\mathrm{PhD}$ theses and various research projects by students and researchers.

Once the ICMP, as the impartial international organisation, overtook the overseeing of the exhumation process from the OHR in 2001 and introduced a DNA-led approach to identification, the number of identifications suddenly increased and by the end of November 2014 the ICMP had issued 14,734 DNA match reports to the local government to be used for official identification. ${ }^{42}$ In $\mathrm{BiH}$, where identifications are conducted in large numbers and victims are mostly commemorated through joint commemorations, the process has multifaceted significance; it gives relatives closure, provides tools for victims to peruse their rights, empowers relatives in the pursuit for justice and gives legal resolution both to cases of missing persons and to families' damage claims from the state or entity. Further, the scientific approach, objective and critical in nature, provides for a scientific account of history, accuracy in truth telling, evidence for war crimes trials and criminal prosecutions. ${ }^{43}$ While the process was undoubtedly a success, it is still not without obstacles today.

One of the biggest problems currently facing the process is the issue of misidentifications, which are most commonly rooted in the roughly 8,000 previously mentioned 'traditional' identifications used prior to the introduction of the DNA-led approach. ${ }^{44}$ In the early days of the post-war efforts, BiH's population was traumatised and poor, its society ravaged, and whose citizens suffered severe material losses during the war. For many people at the time, the identification of a missing relative meant receiving sorely needed international aid in the name of their lost loved one. During this chaotic period, already traumatised people had to undergo a very painful and re-traumatising process of visually identifying their missing loved ones. One has to wonder how many, under such pressures, could have made a mistake?

Due to the changes in both approaches and actors, as well as in the development of new technologies, it has been shown that misidentifications of human remains 
occurred. ${ }^{45}$ Currently, there are some 9,300 excavated cases of human remains, representing around 2,500 individuals stored in $\mathrm{BiH}^{\prime}$ 's mortuaries, that are unidentified (based on extracted DNA profiles). ${ }^{46}$ They are designated as 'NN', from the Latin nomen nescio, which translates into 'name unknown'. These remains either have DNA profiles extracted and generated from a bone sample that lack a DNA match to any reference blood samples given by family members or represent situations where DNA extraction is currently technically impossible. ${ }^{47}$ The reasons for the former are threefold: the remains are not related to the conflict of the 1990s and thus are outside of the mandate of the Law on Missing Persons; there are no living relatives to provide a reference DNA sample or they are a case of misidentification. ${ }^{48}$ These ' $\mathrm{NN}$ ' stored remains have been in this unidentified state of limbo for a long time where the fate of these remains is uncertain, because no agreement can be reached on whether to keep them in storage, bury them in a collective grave or some other action.

Even though attempts have been made to start dealing with these cases since the introduction of the DNA-led approach, the process of these cases' revision only started in June 2013, with the hope that the cases will be resolved and these ghosts of the past will finally be put to rest. ${ }^{49}$

\section{Biopolitical lives of the missing in $\mathrm{BiH}$}

The politics of the process of searching for and identifying the missing in $\mathrm{BiH}$ are multifaceted and have changed and evolved along with the various actors and their agendas. During and in the early days after the conflict, bodies and living prisoners of war (POWs) were exchanged between warring parties, both within the emerging state of $\mathrm{BiH}$ but also between it and its opposing sides (RS, $\mathrm{BiH}$, Serbia and Croatia). One could argue that these exchanges were governed by official actors involved in the process in an effort to strengthen their emerging societies through resolving the fate of the fallen and bringing closure to the families. Considering that 'dead bodies ... have properties that make them particularly effective political symbols', during the conflict the bodies would have held that role even more firmly as symbols of society's heroes, particularly in ethnically divided groups that were fighting to emerge as nations in $\mathrm{BiH} .{ }^{50}$

It is clear that these Commissions could be viewed as an extension of war in their clear goals of resolving the fate of only particular ethno-religious groups. These Commissions dealt in very important capital in war politics at the time: the lives of the living and the bodies of the dead POWs. Through their work being so clearly ethno-religiously defined, the Commissions reinforced the goal of the emerging nations/warring parties by, to borrow Verdery's argument, claiming 'our' living and dead from 'them' and bringing the living and the dead to 'our' territory and burying them in 'our' soil. They used the dead to consecrate the space and territory as 'ours' ${ }^{51}$, having now been given religious burials, and by death having long been associated with religion they have now been re-ascribed a collective, ethnoreligious identity. ${ }^{52}$ In the war of ethno-religious affiliations this further solidified the claims of land, territory and soil belonging to a particular ethno-religious group. 
This was not the only way collective identity was ascribed by the Commissions. We argue that the Commissions also held biopower, in Foucauldian terms, over their POWs, where they governed not only their lives and possible death but also, symbolically, life (the living prisoners) and death (the bodies) itself. The types of biopower held by the Commissions were both individual to each as well as collective to them all, as only through their mutual agreement could exchanges proceed, a process that was mostly based on the biopowers' reciprocity. The exchanges of both living and dead bodies were now controlling life on all sides as they were showcased as stark proof of what 'they' are doing to 'us' and being commemorated as fallen in the fight for the defence/establishment of 'our' nation. It is clear here that the bodies under the authority of the Commissions were not, as Stepputat puts it, 'a blank canvas for the inscription of political agendas', but that the human remains themselves animated social and political processes such as, among others, mourning (by families and nations) and othering (Verdery's 'they' ascribed to these bodies). ${ }^{53}$

One would expect that the materiality of the bodies would 'overturn political agendas and foundational narratives and challenge the power of those who are responsible ${ }^{54}$, but in $\mathrm{BiH}$ they were, and still are, used to support conflicting claims of the past: defence of a country versus founding of a nation. Here what the bodies represent is 'constrained by the reality of the situation' faced by the Commissions. ${ }^{55}$ Themselves on opposing sides, the Commissions - due to the identities of POWs, and at times even of the dead, being known - were already ascribing bodies to particular ethno-religious groups, even if by the person's name alone. They were thus enabling the individuals and society to mourn while also othering those they exchanged. Here the bodies of both living POWs and the dead are a nexus of a 'coupling between the political social system and the biological life system' ${ }^{56}$ Given the nature of the conflict, it is not surprising that every aspect of the body handling was aimed at defining the emerging societies that wanted to be recognised as separate and at shaping the reality of people on each side, as well as the bodies of the captured and the dead.

As already stated, the conflict ended through the signing of the DPA. As a result the international community claimed authority over the parties through brokering the deal as well as through the establishment of the OHR, which the international community made manifest in $\mathrm{BiH}$. Article $\mathrm{V}$ of Annex 7 of the DPA, the article specifically dealing with the issue of missing persons, opened the door for the families of the missing's expectations that identifications of the bodies' physical remains would be individual. It also enabled control of the bodies by the State as the one who is ultimately responsible for them. ${ }^{57}$ The fact that the issue of the missing is directly dealt with in the DPA showcases the international community's agenda to base reconciliation, in part, on accounting for those missing from the war. One could further argue that this was an attempt by the international community to push for unity within $\mathrm{BiH}$; while it did broker a divided country through the DPA, it was attempting to include identifications as a goal of 'the State', not its divided parts, and in turn reinsert all of 'the missing back into the embrace of the state ${ }^{58}$ to reinforce authority over its citizens. ${ }^{59}$ 


\section{Admir Jugo and Senem Škulj}

A more critical reading of this article also highlights the international community's new approach to knowledge production. After the fall of Srebrenica, even though utilising the 'technological feat of looking down from above'60 (referring here to U2 spy airplanes) before the event to produce information on Serb positions, the international community failed to act upon this knowledge. Now it would seem the international community would be in charge of producing and disseminating knowledge on those it failed by utilising services of an international organisation, the ICRC, and presumably acting upon it. The involvement of the ICRC also determined part of the nature of this future process for the international community; resolving the fate of the missing was a humanitarian effort aimed at strengthening the authority of the clearly divided State.

The international community's ideas behind Article V of Annex 7 clearly did not translate into reality. Instead, the process envisioned as a state-run operation was now an extension of the war and run by the former warring parties that made up the State. The role of the bodies of the missing now took on a new dimension; the bodies became biocapital in post-war BiH's division politics. The international community kept the roles it had during the war: an observer and a referee. Now it was the OHR, the political manifestation of the international community's will, that was brokering agreements between the Commissions and territories they claimed as their own, lands the international community recognised as belonging to one side or the other in the DPA. Instead of the missing being returned to the embrace of the State, they were being returned to the embrace of newly emerged societies/nations and the ethno-religious groups they represented. Verdery's 'our' and 'their' started to slowly materialise in post-war BiH. The international community was now complicit in the biopolitics of the dead and, instead of utilising them to unify the heavily divided country, it stood on the side as the bodies of the missing were utilised as powerful biocapital in ethno-religious politics. Still, as the broker of the DPA it had to keep authority of the processes it defined as a priority of reconciliation and thus the Joint Exhumation Process was established. The JEP required the OHR to give approval for actual exhumations and to keep control of both the process and the consequent knowledge. The JEP worked on the premise of the agreement between the former Commission, now transformed into a new form, and the individual identities promised by the DPA, which were now only possible within the collective identity of the ethno-religious affiliations these Commissions represented. The process moved from the State looking for its citizens into a process where particular ethno-religious groups were retrieving members of its nation from 'their' territory and then consecrating remains on 'our' soil, within collective identities inscribed by the DPA.

Another major international actor in this plethora was the ICTY and, having been given primacy over any local actors, it could freely examine any of its agendas. The ICTY's agenda was tied to prosecuting perpetrators, the bodies of the dead served as sites of knowledge production; post-mortem examinations and later DNA testing yielded critical evidence, which the international community, specifically in the context of the Tribunal, levied to secure the criminal convictions of perpetrators. The knowledge produced did not differentiate between individual 
bodies but rather, in a Foucauldian sense of biopolitics, depended on the collective identity of ethno-religious affiliations that the DPA prescribed as the only possible membership in post-war $\mathrm{BiH}$. The body, for Foucault, in relation to government and the administration of populations, is a nexus of three modalities of power: observation, judgment and, most importantly, examination. For Foucault examination is 'the most crucial, since it involves subjecting individual bodies to regimes of expert knowledge and practices' and connecting it to social and political power. ${ }^{61}$ The workings of the ICTY firmly kept control over the knowledge of the bodies away from the individual and within collective identity. Again knowledge production, including on collective but not individual identities, came from the international community; international experts and international agencies that passed the knowledge onto local actors were themselves more concerned with the individual victims. Indeed, the more important knowledge of how to identify or individualise the body was left to local actors to discover for themselves.

An important turning point in these very distinct agendas came with the PHR's involvement. The point marked the first cooperative approach in this process between local and international players. With the involvement of the ICMP taking over the 'international' side of the process from the OHR, and the ICTY pulling out, the agendas of international and local actors seemed to have finally merged, and the process started to transform into a fully cooperative local and international effort. The ICMP's introduction of a DNA-led identification system in 2001 meant that DNA became the new currency in biopolitics. While individual identifications were now the primary goal of those involved in the process, along with the persecution of perpetrators, they could never be fully removed from the collective, ethno-religious identities of former warring parties. Biopower, held through the bodies of the dead by the actors in the process, now evolved to incorporate authority over DNA which derives from it. While the knowledge from DNA is created by the ICMP, it is passed over to the MPI as DNA match reports used by forensic pathologists to derive official individual identifications.

With the DPA bringing such a sudden and unresolved end to the war in Bosnia and Herzegovina, one cannot help but ask; could this have had the impact on the process of recording, recovering and identifying the missing? Given the war has no clear 'victor', could the counting of the missing be used to determine such a side? The numbers of those exhumed and identified are constantly counted by a multitude of different parties: politicians, family members, the media and so on. A common theme in these endeavours is that not as many Serb victims are being exhumed and identified as those Bosniak. These claims have been professed by the different stakeholders in the RS for a very long time using the now common ethno-religious rhetoric. While one might be tempted to view this as just another political ploy contributing to the overall deterioration of $\mathrm{BiH}$ 's political situation, including RS politicians' public threats of a referendum for succession, it is important to note that this view does not have solely an ethno-nationalist form. A recent study showed this kind of criticism has its basis in the perception of some that there is a 'biased and one-sided approach with Bosniak victims being prioritised over Serb and Croat victims' ${ }^{62}$, and that the much higher success in identifying those 
missing from the 1995 Srebrenica genocide are evidence of preferential treatment for victims of this event. ${ }^{63}$ Here collective identities of the dead are again utilised, they are pitted against each other to show that 'our' dead are discriminated against in order to benefit 'their' dead. One important aspect here is that 'their' now also encompasses a smaller part of 'our' that is perceived as somehow getting preferential treatment. While it is interesting to examine, the discussion is beyond the scope of this paper and should be addressed in the future. However, regardless of who 'our' and 'their' are, biopolitics of the dead are evidently still at play in BiH's society today.

As it has been shown, substantial international and local resources and efforts were put towards resolving the fate of all the missing as one of the important methods of reinforcing transitional justice and reconciliation in $\mathrm{BiH}$ and the region. The goal was to unite a heavily divided society that was the product of war, even though these divisions were now solidified with the DPA. One has to question whether reconciliation is achievable within a society where the perception of facts is contrastive among its citizens and the past is still contested.

Nevertheless, things are moving forward. The ICMP, as an international cooperator of the State in this new 'holistic' process, we argue, unifies the political powers searching for the missing into a single power, and has this as one of its goals. Biopowers previously held by the Commission were to be united in the MPI, a state level body co-founded by the ICMP and the state Government. At this point the State was going to strengthen its authority by 'fixing individual identity to nameless remains' and it seemed that individual identities will take primacy over collective, ethno-religious ones. ${ }^{64}$ Five months after the MPI became operational the RS Operational team became active, clearly competing with the MPI's work. While the Operational Team claims that it is 'not formed to locate only missing Serbs, but missing Muslims and Croats' ${ }^{\text {' }}$, it does only present 'authentic documentation about Serbian suffering ${ }^{66}$ in $\mathrm{BiH}$. The formation of the Operational Team showcases that at least some of the local actors are still more interested in reclaiming the dead for their ethno-religious nations instead of for citizens of a joint state. Through the submission of identities via DNA reports to the State, the dead are now being seemingly returned to the State's authority, but as official identifications hinge on living relatives accepting these official identifications, the dead are, we posit, returned under the authority of their living relatives. We argue that while it seems that the international community's attempt to unify local actors in its efforts to identify all of the missing had again failed, through the authority over the dead resting with the families, an unexpected agenda on all sides emerged: the agenda of family members of the missing. All these family members have the same goal: finding and identifying their loved ones and asking for their justice and that all families are united in these efforts. This agenda has even been made official through the formation of the Regional Coordination of Association of Families of the Missing. 


\section{In place of a conclusion}

All that was discussed here has an extreme effect on $\mathrm{BiH}$ and the reconciliation process. On a societal level this is traumatic, as these problems bring society into a transition without an end, posing questions regarding justice and reconciliation. The social, economic, legal and ethical impacts on affected families not having 'closure' are of great significance to 'transitioning' societies. $\mathrm{BiH}$ has made significant strides towards bringing identities back to missing individuals from the forensic point of view, but the biopolitical re-inscribing of collective identities can easily overshadow these efforts. Efforts undertaken in the country can serve as a role-model for other societies dealing with the same issue and recognising possibilities for identifications following mass fatalities. Their shortcomings however must also be recognised and addressed, and it should not be presumed that the model is or should be simply transplanted onto other situations without understanding the particulars of those contexts.

One of the successes of BiH's process is the Law on Missing Persons which provides certain benefits for the families of missing persons. It is clear that problems associated with the process of identifying the missing, such as misidentifications, have legal ramifications for families of the missing. In cases where bodies have been misidentified, legal ramifications could affect families who have had a body of a different person identified as their loved one, but also for the families whose loved one has been buried under somebody else's name. Socially these misidentifications are a cause of trauma, and not just creating that anew but also prolonging the family's trauma in its uncertainty and 'not knowing' their loved one's fate; they create restless ghosts of the pasts bound in identification limbo. Misidentifications also become political biocapital used by all sides for their various goals, including the manipulation of numbers of the identified, allowing for the perception that groups are given preferential treatment to develop.

It is clear that no matter what political roles they take and how they are utilised, dead bodies of the missing in $\mathrm{BiH}$ persists symbolically and materially. The families of all those still unaccounted for are waiting for them to be found and identified in order to put them to rest. Nearly twenty years on from the end of the war $\mathrm{BiH}$ is still in its never-ending 'transition', and resolving the fate of the missing is an important part of that 'transition'. Ghosts of those not found for the past twenty years are still being put to rest. One has to wonder if all these ghosts are ever going to be settled and, if not, who and how will one decide when to stop chasing them? Maybe we should really be asking if this process will ever end since dead bodies clearly still play a crucial role in a divided, post-war $\mathrm{BiH}$. And how should one articulate to those that are still striving for their lost loved one's peace that this might never happen?

\section{Acknowledgements}

This research was generously supported by the European Research Council and was undertaken as a part of the 'Bosnian Bones, Spanish Ghosts' project (ERC grant no. 
241231). The ideas presented in this paper arose from personal experiences gained through participation in the exhumation of sites and identification efforts in $\mathrm{BiH}$ on behalf of the International Commission on Missing Persons and the aforementioned 'Bosnian Bones, Spanish Ghosts' project, neither of which necessarily endorse the views expressed here. The authors would also like to acknowledge their colleagues Sarah Wagner, Damir Arsenijević, Victor Toom, Kitty Lai and the two anonymous reviewers for all their comments on earlier drafts of this paper.

\section{Notes}

1 Data courtesy of the ICMP. See website page 'Bosnia and Herzegovina'. URL: http://www.ic-mp.org/where-we-work/europe/western-balkans/bosnia-andherzegovina/ (accessed 22 November 2014).

2 K. Verdery, The Political Lives of Dead Bodies: Reburial and Postsocialist Change (New York, Columbia University Press, 1999).

3 M. Dobbs, 'Memo to the CIA: Share Your Secrets', Foreign Policy Blog: Mladic in the Hague - Michael Dobbs Explores the Origins of Evil. URL: http://dobbs. foreignpolicy.com/posts/2012/01/27/memo_to_cia_share_your_secrets (accessed 22 November 2014).

4 S. Wagner, 'The Social Complexities of Commingled Remains', in B. J. Adams \& J. E. Byrd (eds), Commingled Human Remains: Methods in Recovery, Analysis, and Identification (Oxford \& San Diego, Academic Press, 2014), pp. 491-506, 495.

5 ICRC, 'Protocol Additional to the Geneva Conventions of 12 August 1949, and relating to the Protection of Victims of International Armed Conflicts (Protocol I)'. URL: http://www.icrc.org/applic/ihl/ihl.nsf/INTRO/470 (accessed 22 November 2014).

6 UN General Assembly, 'Resolution 3220 Assistance and Cooperation in Accounting for Persons Who are Missing or Dead in Armed Conflicts', 6 November 1974. URL: http://daccess-dds-ny.un.org/doc/RESOLUTION/GEN/ NR0/738/22/IMG/NR073822.pdf (accessed 22 November 2014).

7 Office of the High Commissioner for Human Rights, 'International Convention for the Protection of All Persons from Enforced Disappearance', undated. URL: http://www.ohchr.org/EN/HRBodies/CED/Pages/ConventionCED.aspx (accessed 22 November 2014).

8 'Duga lista zločina' ('Long List of Crimes'), Oslobođenje, 29 December 1992, p. 6.

9 The crude rendering of the war posits that the main warring parties were the Army of Bosnia and Herzegovina against the Army of Republika Sprska and between the Army of Bosnia and Herzegovina and the Croatian Defence Council. After the signing of the Washington Agreement in 1994, the Army of Bosnia and Herzegovina and the Croatian Defence Council united in their fight against the Army of Republika Sprska.

10 'Decision on Formation of the State Commission for the Exchange of Prisoners of War', RBiH Official Gazette, 10/92 (1992).

11 Ibid. 
12 'Decision on Formation of the State Commission for Tracing Missing Persons', RBiH Official Gazette, 9/96 (1996).

13 E.-E. Klonowski, 'Forensic Anthropology in Bosnia and Herzegovina: Theory and Practice amidst Politics and Egos', in R. Ferllini (ed.), Forensic Archaeology and Human Rights Violations (Springfield, Charles C. Thomas Publishers, 2007), pp. 148-96.

14 Office of the High Representative in Bosnia and Herzegovina, 'The General Framework Agreement for Peace (Dayton Peace Agreement)', Annex 7, Article 3, no. 2. URL: http://www.ohr.int/dpa/default.asp?content_id=375 (accessed 5 May 2013).

15 'Directive on the formation of a Federal Commission on Missing Persons', FBiH Official Gazette, 15/97 (1997).

16 Human Rights Commission Within the Constitutional Court of Bosnia and Herzegovina (CH/02/10224, CH/03/13212 and CH/03/13213), Decision on Admissibility and Merits, Remza Begzadic and Daut Nukic v. Bosnia and Herzegovina and Republika Srpska. URL: http://www.hrc.ba/database/decisions/ CH-02-10224\%20i\%20dr\%20B.pdf (accessed 15 December 2014).

17 Office of the High Representative in Bosnia and Herzegovina, 'Domestic War Crime Trials and Exhumations', 15 March 2000. URL: http://www.ohr.int/ohrdept/hr-rol/thedept/war-crime-tr/default.asp?content_id=5231 (accessed 7 May 2013).

18 UN Doc. E/CN.4/1996/63, 'Situation of Human Rights in the Territory of the Former Yugoslavia: Report Submitted by Ms. Elisabeth Rehn, Special Rapporteur of the Commission on Human Rights, Pursuant to Commission Resolution 1995/89', 14 March 1996. URL: http://wwwl.umn.edu/humanrts/commission/ country52/63-yugos.htm (accessed 7 May 2013).

19 H. Ranta \& A. Penttila, 'Finnish Forensic Expert Team in Bosnia and Herzegovina', in M. Koskenniemi (ed.), Finnish Yearbook of International Law (The Hague, Kluwer Law International and Ius Gentium Association, 1999), pp. 420-31.

20 J. Rainio, K. Lalu, H. Ranta, K. Takamaa \& A. Penttilä, 'Practical and Legal Aspects of Forensic Autopsy Expert Team Operations', Legal Medicine, 3:4 (2001), 220-32; Ranta \& Penttila, 'Finnish Forensic Expert Team'.

21 Ranta \& Penttila, 'Finnish Forensic Expert Team', 422.

22 ICTY, 'International Tribunal for the Prosecution of Persons Responsible for Serious Violations of International Humanitarian Law Committed in the Territory of the Former Yugoslavia since 1991: Updated Statute of the International Criminal Tribunal for the Former Yugoslavia: Article 8: Territorial and Temporal Jurisdiction'. URL: http://www.icty.org/x/file/Legal\%20Library/Statute/statute_ sept09_en.pdf (accessed 7 May 2013).

23 K. Juhl, The Contribution by (Forensic) Archaeologists to Human Rights Investigations of Mass Graves (Stavanger, Arkeologisk museum i Stavanger, 2005).

24 ICTY, 'ICTY Press Release - First exhumation by ICTY to begin in Srebrenica Area'. URL: http://www.icty.org/sid/7329 (accessed 20 July 2013); ICTY, ICTY Bulletin No 8 - Special: Exhumations (The Hague, ICTY, 1996), p. 1. 
25 United Nations General Assembly Security Council, 'Eight Annual Report of the International Tribunal for the Prosecution of Persons Responsible for Serious Violations of International Humaniarian Law Committed in the Territory of the Former Yugoslavia since 1991', A/56/352-S/2001/865, 17 September 2001. URL: http://www.icty.org/x/file/About/Reports\%20and\%20Publications/ AnnualReports/annual_report_2001_en.pdf (accessed 8 June 2013).

26 M. E. Keough, T. Simmons \& M. Samuels, 'Missing Persons in Post-Conflict Settings: Best Practices for Integrating Psychosocial and Scientific Approaches', The Journal of The Royal Society for the Promotion of Health, 124:6 (2004), 271-5.

27 L. Vollen, 'All That Remains: Identifying the Victims of the Srebrenica Massacre', Cambridge Quarterly of Healthcare Ethics, 10 (2001), 336-40.

28 International Commission on Missing Persons Assistance Act of 2012, H.R. 4344, 112th Cong (2012). URL: http://www.gpo.gov/fdsys/pkg/BILLS-112hr4344ih/ content-detail.html (accessed 15 December 2014).

29 Klonowski, 'Forensic Anthropology in Bosnia and Herzegovina'.

30 E. Huffine, J. Crews, B. Kennedy, K. Bomberker \& A. Zinbo, 'Mass Identification of Persons Missing from the Break-up of the Former Yugoslavia: Structure, Function, and Role of the International Commission on Missing Persons', Croatian Medical Journal, 42:3 (2001), 271-5.

31 L. Yazedjian \& R. Kešetovic, 'The Application of Traditional Anthropological Methods in a DNA-led Identification Process', in B. J. Adams \& J. E. Byrd (eds), Recovery, Analysis, and Identification of Commingled Human Remains (Totowa, Humana Press, 2008), pp. 271-84.

32 Ibid.

33 K. Bomberger, 'AAFS 2012 Atlanta Plenary Session Part 9', presented at American Academy of Forensic Sciences 2012, Atlanta. Available on Youtube. URL: http:// www.youtube.com/watch?v=FdvNEGQ_Ymk (accessed 22 November 2012).

34 'Law on Missing Persons', BiH Official Gazette, 50/04 (2004).

35 'Agreement on Assuming the Role of Co-founders of the Missing Persons Institute of Bosnia and Herzegovina', BiH Official Gazette - International Agreements, 13/5 (2005).

36 Klonowski, 'Forensic Anthropology in Bosnia and Herzegovina'.

37 The text is published in Primjena Zakona o Nestalim Osobama BiH (Application of BßH's Law on Missing Persons) (Sarajevo, BiH Ministry of Human Rights and Refugees, 2007), pp. 39-58.

38 'Decision of the Formation of the Operational Team of Republika Srpska no. 04/1012-1330/08', RS Official Gazette, 56/8 (2008).

39 Bomberger, 'Plenary Session'.

40 Yazedjian \& Kešetovic, 'The application of traditional anthropological methods'.

41 A. Zukanović, N. Sarajlić \& S. Škulj, 'Bosnia and Herzegovina - Physical Anthropology and Legislation', in N. Marquez-Grant \& L. Fibiger (eds), The Routledge Handbook of Archaelogical Human Remains and Legislations - An International Guide to Laws and Practice in the Excavation and the Treatment of Archaeological Human Remains (Oxon \& New York, Routledge, 2011), pp. 92-101. 
42 Data found on the ICMP's 'Western Balkan Tracking Chart'. URL: http://www. ic-mp.org/fdmsweb/index.php?w=wb_chart\&l=en\&s=1\&dt_year=2014\&dt_ month=11\&dt_day=21 (accessed 22 November 2013).

43 A. Jugo \& S. Wastell, 'Disassembling the Pieces, Reassembling the Social: The Forensic and Political Lives of Secondary Mass Graves in Bosnia and Herzegovina', in É. Anstett \& J.-M Dreyfus (eds), Human Remains and Identification: Mass Violence, Genocide and the 'Forensic Turn' (Manchester, Manchester University Press, forthcoming).

44 S. Dedajić, 'U Krajini su Griješili Prilikom Ukopa Žrtava' ('They Made Mistakes in Krajina when Burying Victims'), Dnevni Avaz, 10 August 2013, p. 7.

45 Zukanović, et al., 'Bosnia and Herzegovina'.

46 ICMP, 'Process to Review Cases of Unidentified Mortal Remains in BiH Facilities is Welcomed by BiH Prosecutor and ICMP'. URL: http://www.ic-mp.org/pressreleases/review-of-nn-remains-starts/ (accessed 22 November 2014).

47 A. Brkić-Čekić, 'Porodice nestalih žive u neizvjesnosti' ('Families of the Missing Are Living in Uncertainty'), Oslobođenje, 30 June 2013, p. 5.

48 S. Škulj, 'The Krajina Identification Project (KIP): Challenges Identifying Missing Persons in Krajina Region', presented at 21st International Meeting on Forensic Medicine Alpe-Adria-Pannonia, Sarajevo, 30 May - 2 June 2012; Dedajić, 'They Made Mistakes in Krajina When Burying Victims'.

49 Ibid.; ICMP, 'Process to Review Cases of Unidentified Mortal Remains in BiH'.

50 Verdery, The Political Lives of Dead Bodies, p. 33.

51 Ibid., pp. 97-8.

52 Ibid., pp. 31-2; K. Verdery, 'Dead Bodies Animate the Study of Politics', in A. C. G. M. Robben (ed.), Death, Mourning and Burial: A Cross Cultural Reader (Oxford, Blackwell, 2002).

53 F. Stepputat, Governing the Dead: Sovereignty and the Politics of Dead Bodies (Manchester, Manchester University Press, 2014), p. 26.

54 Ibid., p. 27.

55 Y. Alsheh, 'The Biopolitics of Corpses of Mass Violence and Genocide', in É. Anstett \& J.-M. Dreyfus (eds), Human Remains and Violence: Methodological Approaches (Manchester, Manchester University Press, 2014), p. 27.

56 Ibid., p. 24.

57 C. Bennett, 'Who Knows Who We Are? Questioning DNA Analysis in Disaster Victim Identification', New Genetics and Society, 33:3 (2014), 239-56.

58 S. E. Wagner, To Know Where He Lies: DNA Technology and the Search for Srebrenica's Missing (Berkeley \& Los Angeles, University of California Press, 2008), p. 255.

59 Ibid.

60 Ibid.

61 R. Williams \& P. Johonson, Genetic Policing: The Use of DNA in Criminal Investigations (London \& New York, Routladge, 2011) pp. 25-6.

62 M. O'Reilly, 'Catastrophe, Memory and Gendered Activism: Peacebuilding in Post-Conflict Bosnia-Herzegovina', unpublished PhD Thesis, Department of War Studies, King's College London, 2014, p. 214. 
Admir Jugo and Senem Škulj

63 Ibid., pp. 214-15.

64 Wagner, To Know Where He Lies, p. 255.

65 Operational Team of the Republic of Srpska for Tracing Missing Persons, 'About Us'. URL: http://www.nestalirs.com/onama.html (accessed 22 November 2014).

66 Operational Team of the Republic of Srpska for Tracing Missing Persons, 'Exhumations'. URL: http://www.nestalirs.com/indexcir.html (accessed 22 November 2014). 